\title{
CUSTOMER ENGAGEMENT AND LOYALTY ISSUES IN OMNICHANNEL FAST-FOOD INDUSTRY
}

\author{
Ing@ Grace Phang* \\ Faculty of Business, Economics and Accountancy, Universiti Malaysia Sabah \\ Jing-En Ng \\ Faculty of Business, Economics and Accountancy, Universiti Malaysia Sabah \\ Kim-Shyan Fam \\ School of Management, Harbin University of Commerce
}

\begin{abstract}
Building on Social Exchange Theory and Congruity Theory, this study aims to examine the relationships between channel integration quality (i.e., channel-service configuration and integrated interaction) and congruity (i.e., self-brand image congruity and value congruity) towards customer engagement; as well as the impacts of customer engagement on customer behavioural loyalty (i.e., repurchase intention and positive WoM). Adopting convenience and snow-ball sampling methods, a total of 151 valid questionnaires were collected and analysed using SPSS 25 and SmartPLS 3.0 software. Congruity aspects play significant roles in influencing customer engagement, while channel integration qualities do not. This result could be attributed to the unique characteristics of the fast-food products and Malaysian fast-food consumers. Importantly, customer engagement influences both transactional (i.e., repurchase intention) and emotional (i.e., intention to spread positive word of mouth) loyalty positively. The findings provide useful insights to both academicians and practitioners to plan for different omnichannel strategy in the effort to increase customer engagement and desired post purchase behaviours.
\end{abstract}

Keywords: omnichannel, fast-food, customer engagement, channel integration quality, congruity, behavioural loyalty

Received: 23 October 2020

Accepted: 22 May 2021

https://doi.org/10.33736/ijbs.4313.2021

\section{INTRODUCTION}

In the past two decades, online channel and mobile accessibility (Verhoef et al., 2015) have changed the transaction of goods and services radically. Digital platforms enable greater level of interactivity and flexibility (Islam et al., 2018), while the evolution of multichannel marketing allows consumers to access to products freely via smartphones, computer and calling services (Piotrowicz \& Cuthbertson, 2014). Consumers are no longer stick to visiting the stores physically but are allowed to move and shop across different channels (Gao \& Su, 2017; Lee et al., 2019). Cross shopping in which consumers can surf at a channel, and complete the purchasing transaction

\footnotetext{
- Corresponding author: Faculty of Business, Economics and Accountancy, Universiti Malaysia Sabah, Jalan UMS 88400, Kota Kinabalu, Sabah, Malaysia; Email: gracep@ums.edu.my
} 
at the other channel (Bang et al., 2013) becomes common. However, multiple channel system consists of detached channels are argued to lead to fragmented supply chains and inconsistent customer experiences (Saghiri et al., 2017).

Omniretailing is the current trend in retailing (Wong, 2020) which creates greater customer engagement and to better serve channel customers who appreciate convenient shopping options. Rather than solely rely on a single channel or using multiple unintegrated channels, retailers have turned to omnichannel strategies which enable better coordination of processes and technologies across channels (Park \& Kim, 2019). In Malaysia, e-commerce has experienced an exponential growth in the recent years. Despite the industry experts' arguments that traditional retailers cannot depend solely on physical store to grow, e-commerce is predicted to be a complement rather than a competitor to the offline commerce (Wong, 2020). Omnichannel retailing strategies such as cross-channel capabilities, robust mobile app features, multiple fulfilment options and new customer service channels (Grant, May 16 ${ }^{\text {th }} 2019$ ) have allowed even low involvement product providers such as fast-food restaurants to gain competitive advantage. Cheah et al. (2020) argued that omnichannel retailing has allowed Malaysian consumers to have a "seamless, meaningful and long-lasting experience". In fact, increase engagement through multiple channels is in accordance to increase in purchase volume (Orendorff, 2018), especially when these channels are integrated.

Customer engagement has been recognised by marketing scholars and remains as one of the main research area in marketing (Maslowska et al., 2016; Vivek et al., 2014). It is examined and studied in different contexts such as banking (Moliner et al., 2018); hotel (Islam et al., 2019); and even for social media platform (de Oliveira Santini et al., 2020). Despite drawing huge interests among marketing practitioners (Pick et al., 2010; Sashi, 2012), customer engagement remains unclear and could be viewed along short- or long-term exchange relationship dimensions (Sashi, 2012). Furthermore, customer engagement is highlighted in digital marketing (de Oliveira Santini et al., 2020; Moran et al., 2014) where digital platforms allow individuals "to engage in increasing levels of interactivity with others to meet personal or mutual objectives" (Islam et al., 2018). Since digitalization is going to be a catalyst for change in the foodservice sector for consumers in ASEAN countries (Euromonitor International, 2019), making a food purchase an enjoyable experience is important to consumers (Euromonitor International, 2019) and customer engagement could be a competitive advantage (Kumar \& Pansari, 2016) for omnichannel fast-food retailers.

The recent research examining customer engagement and omnichannel are either examining the functional aspects of omniretailing (e.g., channel integration quality; Lee et al., 2019) or focusing on the consumer personality and brand community on transactional outcome (e.g., repurchase intention, Islam et al., 2018). Studies bridging customer engagement through omniretailing and channel integration remains scarce (Hollebeek et al., 2016; Lee et al., 2019), particularly in the context of the fast-food industry. Cheah et al. (2020) argued that examination of omnichannel retailing is more than channel integration. This study aims to present a comprehensive examination of the relationships between customer engagement and the functional aspects of channel integration quality (e.g., channel-service configuration and integrated interaction) as well as the emotional aspects of perceived congruity (e.g., self-brand image congruity and value congruity). This paper argues on the importance of perceived congruity between consumers and the brands they feel engage to and buy in the context of omnichannel among fast-food providers in Malaysia. Congruity has been proven as an important factor influencing consumer choices (Phua \& Kim, 2018). It is postulated that people are drawn to products or brands that are congruent with their own image and 
values (Aaker, 1996), which lead to greater engagement with these products or brands, and further contribute to repurchase intention and positive word of mouth (WoM). Nevertheless, such consumer studies are insufficient. Although some researchers argue the customer engagement should result in both transactional and non-transactional outcomes (e.g., positive WoM; CambraFierro et al., 2013), it has yet been studied comprehensively. Hence, this study further addressed the impacts of customer engagement on transactional and non-transactional loyalty dimensions (i.e., repurchase intention and intention to spread positive WoM) to help practitioners to identify the critical area to enhance customer engagement and increase behavioural loyalty in omnichannel fast-food retailing context.

\section{THEORIES AND HYPOTHESIS DEVELOPMENT}

Social Exchange Theory (SET) proposes that a decision is made based on an individual's judgement on the trade-off between costs and benefits (Kelley \& Thibaut, 1978). When two parties involved, individuals could be accounted to the economic benefits vs. costs, social benefits vs. costs, or the mixture of both (Guo et al., 2017). Relationship will be continued as long as both parties gain mutual benefits (Choi et al., 2008). When one party feels that he or she owes the other party a favour, he or she will be obliged to return the favour (Blau, 2017). This widely explaining firm-customer relationship (Cropanzano \& Mitchell, 2005) in identifying what rewards customers expect to receive to continue their engagements with firms (Emerson, 1976). Firms are assumed to focus on getting customers' attention by creating expectations on rewards.

Ample of brand and consumer studies also use SET to examine customer engagement (Harrigan et al., 2018; Simon et al., 2016; Verleye et al., 2014; Zainol et al., 2016). In Verleye et al. (2014)'s study for instance, "social exchange" is labelled to the exchange of benefits by a party that goes beyond economy obligations (e.g., positive WoM). These positive consumer affects will result in feedbacks which benefit the firm and its stakeholders (Lawler, 2001). The focus of SET on equity and reciprocity represents an ideal theoretical framework for customer engagement (Lee et al., 2019), especially in the context of omnichannel retailing where more interactivity and flexibility are allowed by the digital platforms for consumers to fulfil their personal or mutual needs (Islam et al., 2019).

Congruity Theory (CT; Tannenbaum \& Osgood, 1955) on the other hand, further decsribes the encouragement of communication between people. According to CT, consumers who have a harmonised emotion towards a brand, event or experience proclaim to have positive attitudes and behaviors (Lee \& Jeong, 2014). The congruency confirms and strenghtens the perception (Islam et al., 2018) and results in greater engagement. In case of a omnichannel retailing context, the greater the congruency between the two parties (eg. consumer and the omnichannel retailer), the greater the favourable responses towards the restaurant.

\subsection{Behavioural Loyalty: Repurchase Intention and Positive Word of Mouth}

Repurchase intention describes the probability to continue purchase products from the same vendor or store in the future (Chiu et al., 2009) among satisfied customers (Hellier et al., 2003). It has been studied and associated with loyalty and commitment by many scholars (Bitter \& Grabner-Kräuter, 2016; Cheung et al., 2015; Erciş et al., 2012; Srivastava \& Sharma, 2013). However, some argue 
that repurchase intention might not reflect true behavioural loyalty as some repurchases could be attributed to convenience or necessity needs rather than real engagement (Chi et al., 2009; Tseng et al., 2004). Loyalty is hence should cover other behavioural aspects such as intention to spread positive WoM.

Scholars claim WoM to be among the most important responses in forming direct customer relationship (Beerli et al., 2007; Nijssen et al., 2003). It refers to the extent where individuals will communicate and tell others about their personal experiences and evaluations (Anderson, 1998) which could be either positive or negative experiences. Customers who are engaged to a product or brand are more likely to pass along positive WoM to their peers and family (Christofi et al., 2019). Many successful brands such as Amazon.com and Apple are making customers their strong advocacy by putting much effort in customer engagement (de Matos \& Rossi, 2008).

\subsection{Channel Integration Quality}

Despite much effort has been done to examine the drivers (e.g., involvement), definition, measurement and outcomes (e.g., loyalty) for customer engagement (Wong \& Merrilees, 2015; Zhang et al., 2017), the understanding of customer engagement remains vague. Vivek et al. (2012) for instance define it as "having multiple layers of relationship and touch point with the customer". Pick et al. (2010) defines it as a customer's behaviour that have a brand or firm focus but it is something that goes beyond transaction and leads to consequence of motivational drivers towards the firm or brand. These behaviours can be positive (e.g., repurchase of goods and sharing positive message on the internet) or negative (e.g., boycotting or taking lawsuit against the firm; Pick et al., 2010). Others believe that it is different from customer's attitude (i.e.: trust, satisfaction, and commitment; Pick et al., 2010), and distinct from trust, commitment, and loyalty (Bowden, 2008). Islam et al. (2019) found that customer engagement contributes to repatronage intention and brand experience in hotels.

In the case of retailing, multiple channels could be an effective competitive advantage (Wakolbinger \& Stummer, 2013) to retailers who are trying to upgrade and improve their channel quality (Verhoef et al., 2015). Integrated multiple channels allows retailers and business to experience various benefits in terms of customer loyalty, increase shopping enjoyment and improve purchase intention (Islam et al., 2019), especially those with good channel integration quality (Alexander \& Cano, 2019). Two quality components are considered as critical, namely channel-service configuration and integrated interactions (Sousa \& Voss, 2006). Channel-service configuration is measured by the breadth of channel-service choice and transparency of channelservice configuration (Lee et al., 2019). Breath of channel-service choice refers to the degree where customers can choose and move around different channels for the service or doing purchase transactions. Consumers are allowed to "use the channel interchangeably during the search, purchase and post purchase phases" to enjoy "a holistic shopping experience" (Islam et al., 2019). The logic is to choose the most convenient and effective channel (Sousa \& Voss, 2006).

On the other hand, transparency of channel-service configuration refers to the degree where customers are aware of any offered channels and service by the retailers and the different service attributes between different channels. It describes how a firm constantly provide relevant and consistent information across all channels (Sousa \& Voss, 2004), without contradicted information which could lead to confusion (Schoenbachler \& Gordon, 2002). Customer confusion is the last 
thing that a retailer wants (Bitner et al., 2002). A channel transparency is high when most customers are well aware of the existence of the channels. Corroborating Lee et al. (2019), a high level of channel-service configuration will contribute to a high level of customer engagement. Based on the discussion above, the hypothesis is formed:

\section{H1: Channel-service configuration positively affects customer engagement}

Sousa and Voss (2006) proposes two sub-dimensions to measure integrated interaction, namely content consistency and process consistency. Content consistency refers to the consistency of the content that is included and provided in the channels, such as price, description of the product and service, warrant service, and etc. (Lee et al., 2019). Content consistency plays an important role in providing consumers a comprehensive and solid information during their information searching process (Oh \& Teo, 2010). Customers are more willingly to share consistent contents (Simon et al., 2016) as they feel psychologically safer to spread the content. The reliability and believability of the content is positively related to their likelihood towards the retailers and helps to develop brand experience (Gabisch \& Gebwu, 2011) and enhance customer engagement.

Process consistency on the other hand, describes the purchasing processes customers experience across different channels (Sousa \& Voss, 2006). It is important to note that customers do not welcome different experiences at different channels, especially when some channels are poorly designed and frustrate them (Loiacono et al., 2007). Consistency in term of service and product offerings is also critical to consumers. Hence, when a fast-food restaurant customer is pleased with the consistency of the content and the process experienced via the omnichannel platforms, he or she will willingly engage with the restaurant. Based on this, the hypothesis is formed:

\section{H2: Integrated interaction positively affects customer engagement}

\subsection{Self-Brand Image Congruity}

Consumers are found not only refer to the functional needs but also emotional attachment to a brand or firm (Moliner et al., 2018) where both contribute to greater engagement (Islam et al., 2018). Customer with a higher level of self-brand image congruity tend to feel highly related to a brand or firm (Moliner et al., 2018) and often to be more attached, which result in better brand attitude and higher purchase intention (Phua \& Kim, 2018). In Shirkhodaie and Rastgoo-deylami (2016)'s study, greater brand image-consumer congruity is found to lead to greater brand appraisal and eventually result in higher level of customer engagement. Consumers will then engage in repurchase and tell their family and peers (i.e., Positive WoM; Larasati \& Hananto, 2012). It is hence concluded that self-brand congruity is an important aspect for customers to show positive behaviours towards a brand or firm (Su \& Reynold, 2017).

In retail, the self-brand image congruity describes the degree of the customer's pursued image of the self is connected with the image of the service or product provided by the retailers (Pick et al., 2010). Adopting the congruity theory, when a customer has a harmonized connection with the perceived image of a fast-food retailer, positive behaviour and attitude could be observed (Islam et al., 2018). From the discussion, the hypothesis is developed: 


\subsection{Value Congruity}

In business, value congruity is related to value similarity between customers and firms (Lee \& Jeong, 2014). Value congruity describes the connection between customer's own value perspective and the value of the product or service (Shirkhodaie \& Rastgoo-deylami, 2016). This happens when both consumers and retailers offer something in trade with equal value (subjectively judged by themselves) which enable greater engagement (Enz, 2019). Customers stick to firms that provide them similar perceived values (e.g., green product, sustainability, and anti-child labour etc). Despite its importance to create customer engagement (Islam et al., 2018), the study of value congruity is relatively scarce (Lee \& Jeong, 2014). Shirkhodaie and Rastgoo-deylami (2016) in their study argued that value congruity does not directly affect WoM but more on the commitment, which is needed for customer engagement to take place (Bowden, 2008). It is hence postulated that the higher perceived value congruity between the customers and the fast-food retailer, the higher their engagement with a brand or firm will be. Based on this, the hypothesis is formed:

\section{H4: Value Congruity positively affects Customer Engagement}

\subsection{Customer Engagement and Customer Loyalty}

Repurchase intention is frequently projected as one of the positive outcomes of customer engagement (Islam et al., 2019). However, some (e.g., Chi et al., 2009; Tseng et al., 2004) argue that consumers could stick to a product or brand due to convenience instead of real engagement, hence call for more in-depth studies to find out the underlying reasons and to clarify the relationship between customer engagements and repurchase intention.

Positive WoM is able to change an unfavourable condition to favourable, in which higher degree of customer-firm connection (engagement) encourages more positive WoM (Christofi et al., 2019). De Vries and Carlson (2014) confirmed the relationship between customer engagement and customer's behaviour in social media context. It is postulate that the same relationship could be formed in a retail context. Based on this, the hypothesis is formed:

\section{H5: Customer Engagement positively affects Repurchase Intention}

\section{H6: Customer Engagement positively affects Positive Word of Mouth}

\section{METHODOLOGY}

This study aims to examine i) the relationship between channel-service configuration and integrated interaction with customer engagement; ii) the relationship between self-brand image congruity and values congruity with customer engagement; and lastly, iii) the relationship between customer engagement and behavioural loyalty (repurchase intention and positive word-of-mouth). The framework of the study (Figure 1) is building on the SET and Congruity Theory. The relationships between channel-service configuration and integrated interaction with customer engagement and the behavioural loyalty were explained by SET; while Congruity Theory explained the relationship between self-brand image congruity and values congruity with customer engagement and behavioural loyalty. 
Figure 1: Conceptual Framework

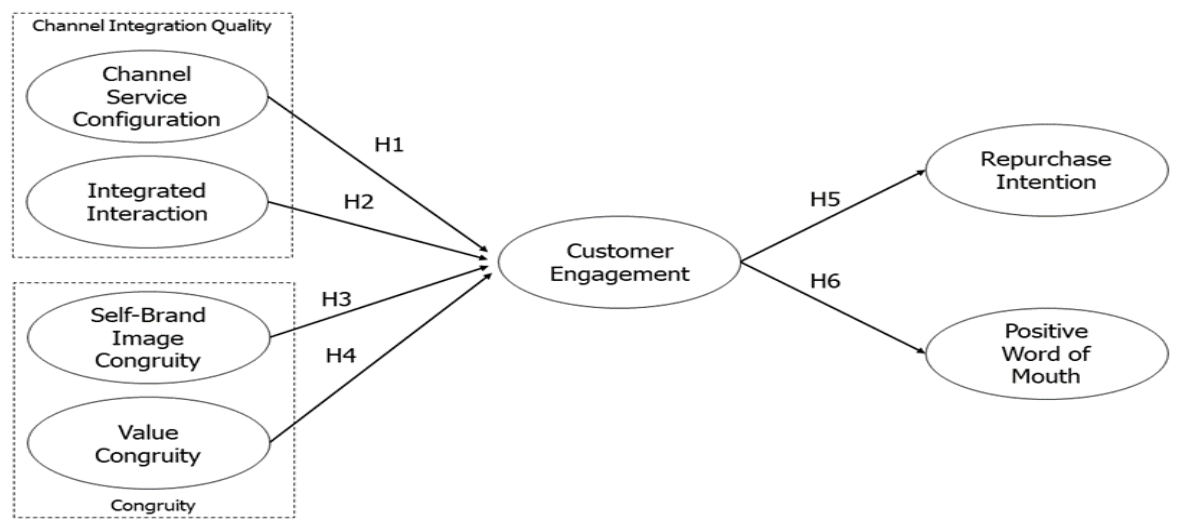

A cross sectional survey was carried out via self-administrated questionnaire. The respondents were pre-screened to ensure the target respondents are fast-food consumers who use multiple channels to buy fast-food. These channels include physical stores, online purchase via host platform, or other platforms (e.g., ordering McDonald's burger via GrabFood). Due to the undetermined population size, convenient sampling and snowball sampling methods were adopted. The former is used to choose subjects conveniently from the targeted group according to the most accessible subjects and the respondents are often suit certain criteria (Marshall, 1996), whilst snowball sampling method enable researcher to find the next potential respondent from the current respondent who has experience in using more than one channel to purchase fast-food (Sekaran \& Bougie, 2014).

Seven variables were tested in this study, namely Channel-Service Configuration, Integrated Interaction, Self-Brand Image Congruity, Value Congruity, Customer Engagement Repurchase Intention and Positive Word-of-Mouth (WoM). Channel-Service Configuration was measured with Breadth of Channel Service Choice and Transparency of Channel-Service Configuration as the first order constructs. Also, Content Consistency and Process Consistency were the first order constructs for Integrated Interaction. Finally, Conscious Attention, Enthused Participation, and Social Connection were the first order constructs for Customer Engagement. Two stage approach was used in the making of second order construct for the variables which will then be used for hypothesis testing. All variables mentioned are measured by using five-point Likert scale ranging from strongly disagree (1) to strongly agree (5). Breath of channel service choice, transparency of service channel configuration, content consistency and product consistency were each measured with four items each, adopted from Lee et al. (2019). Self-brand image congruity was measured with five items, adapted from de Vries and Carlson (2014) and value congruity was measured with three items, adopted from Lee and Jeong (2014). Adopted Lee et al. (2019)'s study, the three sub dimensions of customer engagement, namely conscious attention was measured with six items, enthused participations with 5 items, social connection with three items. Both repurchase intention and intention spread positive WoM were measured with four items each, adopted from Lee et al. (2019). 
A pre-test aimed to identify the types of fast-food restaurant the participants frequented and the channels used was conducted. A total of 10 respondents took part in the pre-test and the result suggested the preferred choice of fast-food restaurants in Malaysia (e.g., McDonald, KFC, Domino's Pizza etc.) which served as examples in the main test. The pre-test also showed that respondents using various channels to purchase fast-food. Later, ten cognitive interviews were carried out to determine the accuracy and measurability of the items measured. This is to ensure instructions and the questions were comprehensible, without grammatical and typo errors.

A priory test in G-Power analysis with effect size of 0.15 and significant level of $80 \%$ (Cohen, 2013) was carried out to determine the minimum sample size. From a total of 200 questionnaires distributed, 156 responses were collected (78\% response rate) and 151 was found valid, which was higher than the required minimum sample size of 98.

\section{RESULTS AND DISCUSSION}

The review of the fast-food consumption patterns indicated that the majority of young adult respondents consumed fast-food at least once a week. The common channels used by these respondents included personal visit to physical store, online ordering, call-delivery and order via GrabFood. In brief, the respondents are young adults who have vast experiences in fast-food consumption. The have tried various channels and hence considered suitable respondents in this study.

Due to a single method, common method variance could be a concern. Podsakoff et al. (2003) suggested that the total variance for the single component should be less than $50 \%$ to reflect no concern for common method variance. To ensure the data is free from common method variance, the Harman's single factor test was carried out with a total of 46 components. The test result indicated a total of $30.18 \%$ total variance explained by the first component, implied that CMV did not affect the data and the result.

Statistical Package for Social Science (SPSS) version 25 and Smart Partial Lease Square (Smart PLS) version 3 were used to perform reliability and validity testing as well as hypothesis testing. The mean scores and standard deviation for all variables (refer to Table 1) indicated that respondents are most agree with Breadth of channel service choice $(m=3.8278)$ while least agree with Enthused participation $(\mathrm{m}=2.4517)$. However, respondents tend to be neutral regarding Social Connection $(\mathrm{m}=2.9823, \mathrm{sd}=1.02689)$ and Value Congruity $(\mathrm{m}=3.1501, \mathrm{sd}=0.89830)$.

Table 1: Mean and Standard Deviation for the Studied Variables

\begin{tabular}{lcc}
\hline \hline \multicolumn{1}{c}{ Variables } & Mean & Standard Deviation \\
\hline Channel-service Configuration & 3.7864 & 0.80556 \\
Integrated Interaction & 3.3518 & 0.78706 \\
Customer Engagement & 2.8992 & 0.80510 \\
Self-Brand Image Congruity & 2.8185 & 0.82861 \\
Value Congruity & 3.1501 & 0.89830 \\
Repurchase Intention & 3.2517 & 0.84582 \\
Positive Word-of-Mouth (PWoM) & 2.7666 & 0.86201 \\
\hline \hline
\end{tabular}




\subsection{Convergent Validity and Internal Consistency Reliability}

Convergent validity and internal consistency were determined by examining the outer loadings, composite reliability (CR) and average variance explained (AVE). Table 2 shows the loadings and AVE values. Factor loadings should be above 0.5 (Osborne \& Costello, 2005), CR should be above 0.7 and AVE should be above 0.5 (Hair et al., 2010). Refer to Table 2, all cross loadings, AVE and CR were above the acceptance levels, indicated acceptable convergent validity.

Table 2: Internal Consistency Reliability and Convergent Validity

\begin{tabular}{|c|c|c|c|c|c|}
\hline Construct & Measurement Item & Loading & AVE & CR & $\begin{array}{c}\text { Cronbach's } \\
\text { Alpha }\end{array}$ \\
\hline $\begin{array}{l}\text { Channel-Service } \\
\text { Configuration }\end{array}$ & $\begin{array}{c}\text { Breadth of Channel- } \\
\text { Service Choice } \\
\text { Transparency of } \\
\text { Channel-Service } \\
\text { Configuration }\end{array}$ & $\begin{array}{l}0.926 \\
0.904\end{array}$ & 0.837 & 0.911 & 0.806 \\
\hline $\begin{array}{l}\text { Integrated } \\
\text { Interaction }\end{array}$ & $\begin{array}{l}\text { Content Consistency } \\
\text { Process Consistency }\end{array}$ & $\begin{array}{l}0.874 \\
0.916 \\
\end{array}$ & 0.801 & 0.890 & 0.754 \\
\hline $\begin{array}{l}\text { Customer } \\
\text { Engagement }\end{array}$ & $\begin{array}{c}\text { Enthused } \\
\text { Participation } \\
\text { Conscious Attention } \\
\text { Social Connection }\end{array}$ & $\begin{array}{l}0.876 \\
0.875 \\
0.852 \\
\end{array}$ & 0.753 & 0.901 & 0.836 \\
\hline $\begin{array}{l}\text { Self-Brand Image } \\
\text { Congruity }\end{array}$ & $\begin{array}{l}\text { SBIC01 } \\
\text { SBIC02 } \\
\text { SBIC03 } \\
\text { SBIC04 } \\
\text { SBIC05 }\end{array}$ & $\begin{array}{l}0.770 \\
0.886 \\
0.875 \\
0.852 \\
0.777 \\
\end{array}$ & 0.695 & 0.919 & 0.889 \\
\hline Value Congruity & $\begin{array}{l}\text { VC01 } \\
\text { VC02 } \\
\text { VC03 } \\
\end{array}$ & $\begin{array}{l}0.875 \\
0.896 \\
0.885 \\
\end{array}$ & 0.784 & 0.916 & 0.862 \\
\hline Conscious Attention & $\begin{array}{l}\text { CA01 } \\
\text { CA02 } \\
\text { CA03 } \\
\text { CA04 } \\
\text { CA05 } \\
\text { CA06 }\end{array}$ & $\begin{array}{c}0.765 \\
0.805 \\
0.841 \\
0.832 \\
0.83 \\
0.791 \\
\end{array}$ & 0.658 & 0.920 & 0.896 \\
\hline $\begin{array}{l}\text { Enthused } \\
\text { Participation }\end{array}$ & $\begin{array}{l}\text { EP01 } \\
\text { EP02 } \\
\text { EP03 } \\
\text { EP04 } \\
\text { EP05 } \\
\end{array}$ & $\begin{array}{l}0.772 \\
0.892 \\
0.881 \\
0.864 \\
0.774 \\
\end{array}$ & 0.702 & 0.922 & 0.893 \\
\hline Social Connection & $\begin{array}{l}\mathrm{SC} 01 \\
\mathrm{SC} 02 \\
\mathrm{SC} 03 \\
\end{array}$ & $\begin{array}{l}0.840 \\
0.876 \\
0.840 \\
\end{array}$ & 0.726 & 0.888 & 0.815 \\
\hline $\begin{array}{l}\text { Repurchase } \\
\text { Intention }\end{array}$ & $\begin{array}{l}\text { RI01 } \\
\text { RI02 } \\
\text { RI03 } \\
\end{array}$ & $\begin{array}{l}0.883 \\
0.871 \\
0.811 \\
\end{array}$ & 0.712 & 0.908 & 0.864 \\
\hline
\end{tabular}




\begin{tabular}{|c|c|c|c|c|c|}
\hline Construct & "Measurement Item & Loading & AVE & $\overline{C R}$ & $\begin{array}{c}\text { Cronbach's } \\
\text { Alpha }\end{array}$ \\
\hline & RI04 & 0.806 & & & \\
\hline Positive Word of & PWOM01 & 0.783 & 0.725 & 0.913 & 0.873 \\
\hline Mouth & PWOM02 & 0.848 & & & \\
\hline & PWOM03 & 0.895 & & & \\
\hline & PWOM04 & 0.877 & & & \\
\hline
\end{tabular}

\subsection{Discriminant Validity}

Discriminant validity refers the extent of the construct correlates on each other to find out any potential overlapping of the constructs. Table 3 shows the Fornell-Larcker's Criterion (2018) result for each of the dimension tested, the square roots of AVEs exceeding the values of the inter construct on the same columns and rows.

Table 3: Fornell-Larcker's Criterion

\begin{tabular}{lccccccc}
\hline \hline & CS Con & CE & In I & PWOM & RI & SBIC & VC \\
\hline CS Con & $\mathbf{0 . 9 1 5}$ & & & & & & \\
CE & 0.293 & $\mathbf{0 . 8 6 8}$ & & & & & \\
In I & 0.594 & 0.300 & $\mathbf{0 . 8 9 5}$ & & & & \\
PWOM & 0.199 & 0.607 & 0.184 & $\mathbf{0 . 8 5 2}$ & & & \\
RI & 0.213 & 0.684 & 0.236 & 0.626 & $\mathbf{0 . 8 4 4}$ & & \\
SBIC & 0.248 & 0.663 & 0.333 & 0.439 & 0.446 & $\mathbf{0 . 8 3 4}$ & \\
VC & 0.273 & 0.558 & 0.215 & 0.342 & 0.389 & 0.583 & $\mathbf{0 . 8 8 6}$ \\
\hline \hline
\end{tabular}

Notes: CS Con=Channel Service Configuration; $\mathrm{CE}=$ Customer Engagement; In I=Integrated Interaction;

$\mathrm{PWoM}=$ Positive WoM; Ri= Repurchase Intention; $\mathrm{SBIC}=$ Self-Brand Image Congruity; VC=Value Congruity

Next, Monotrait ratio of correlations (HTMT) was performed. Refer to table 4, the value were found lower than the threshold of HTMT 0.85 suggested by Kline (2015), indicates that discriminant validity is established for the constructs in this study. In brief, the results of FornellLarcker's Criterion and HTMT results indicate discriminant validity is achieved in this study.

Table 4: HTMT Criterion

\begin{tabular}{lccccccc}
\hline \hline & CS Con & CE & In I & PWOM & RI & SBIC & VC \\
\hline CS Con & & & & & & & \\
CE & 0.354 & & & & & & \\
In I & 0.775 & 0.373 & & & & & \\
PWOM & 0.246 & 0.706 & 0.236 & & & & \\
RI & 0.256 & 0.803 & 0.291 & 0.718 & & & \\
SBIC & 0.296 & 0.767 & 0.399 & 0.497 & 0.505 & & \\
VC & 0.327 & 0.654 & 0.263 & 0.396 & 0.450 & 0.667 & \\
\hline \hline
\end{tabular}

Notes: CS Con=Channel Service Configuration; $\mathrm{CE}=$ Customer Engagement; In I=Integrated Interaction;

$\mathrm{PWoM}=$ Positive WoM; Ri= Repurchase Intention; SBIC=Self-Brand Image Congruity; VC=Value Congruity 


\subsection{Lateral Collinearity Assessment (Variance Inflator Factor, VIF)}

Lateral collinearity issue has to be avoided before the structural model evaluation. This is due to the factor that lateral collinearity issue may facade the strong casual effect in the model and further caused mislead of the result although the criteria of discriminant validity were met (Kock \& Lynn, 2012; Osborne \& Costello, 2005). The result of the lateral collinearity test, where all inner VIF values were less than 5 as proposed by Hair et al. (2017) or 3.3 suggested by Diamantopoulos and Siguaw (2006). This means that the collinearity does not reach the critical level and not issue in estimating PLS path model.

\subsection{Hypothesis Testing}

Bootstrapping procedure with 500 subsamples were performed to assess the structural model. The $\mathrm{R}^{\mathbf{2}}$ value indicates the variance in the dependant variable that is explained by the independent variable and is found higher than the minimum value of 0.25 suggested by Hair et al. (2008). Table 5 presents the results of hypothesis testing.

As expected, the strongest relationship was found between customer engagement and repurchase intention $\left(\beta=0.684, \mathrm{t}=14.60 ; \mathrm{f}^{2}=.877\right)$ and positive $\operatorname{WoM}\left(\beta=0.607, \mathrm{t}=11.278 ; \mathrm{f}^{2}=.583\right)$ hence supported H5 and H6. Refer to Cohen (2013), the effect size measured should be in the value of $0.01,0.20,0.50$, and 0.80 to represent very small, small, medium, and large effect respectively. Customer engagement has large and medium size effects on repurchase intention and positive WoM. Both self-brand image congruity $(\beta=0.489, \mathrm{t}=7.201)$ and value congruity $(\beta=0.242, \mathrm{t}=$ 3.561) significantly predicted customer engagement, hence support $\mathrm{H} 3$ and $\mathrm{H} 4$. Nevertheless, both variables show small effect sizes towards customer engagement $\left(\mathrm{f}^{2}=0.291\right.$ and $\mathrm{f}^{2}=0.074$ respectively). Contradictory, both channel service channel configuration and integrated interaction were found to have no significant relationships with customer engagement, with $t$ values lesser than 1.645 and $\mathrm{p}$ value higher than .05. Hence, $\mathrm{H} 1$ and $\mathrm{H} 2$ are not supported.

Table 5: Results of Hypothesis Testing

\begin{tabular}{|c|c|c|c|c|c|c|c|c|}
\hline & Relationship & $\begin{array}{c}\text { Std } \\
\text { Beta }\end{array}$ & $\begin{array}{c}\text { Std } \\
\text { Error }\end{array}$ & $\begin{array}{c}\text { T- } \\
\text { value }\end{array}$ & $\begin{array}{c}\text { P- } \\
\text { value }\end{array}$ & "Decision & $\overline{\mathbf{R}^{2}}$ & $\overline{F^{2}}$ \\
\hline H1 & $\begin{array}{l}\text { Channel-Service } \\
\text { Configuration } \rightarrow \\
\text { Customer } \\
\text { Engagement }\end{array}$ & 0.086 & 0.079 & 1.078 & 0.282 & Rejected & 0.494 & 0.009 \\
\hline $\mathrm{H} 2$ & $\begin{array}{l}\text { Integrated } \\
\text { Interaction } \rightarrow \\
\text { Customer } \\
\text { Engagement }\end{array}$ & 0.033 & 0.079 & 0.425 & 0.671 & Rejected & & 0.001 \\
\hline $\mathrm{H} 3$ & $\begin{array}{l}\text { Self-Brand Image } \\
\text { Congruity } \rightarrow \\
\text { Customer } \\
\text { Engagement }\end{array}$ & 0.489 & 0.068 & 7.201 & 0 & Supported & & 0.291 \\
\hline $\mathrm{H} 4$ & $\begin{array}{l}\text { Value Congruity } \rightarrow \\
\text { Customer } \\
\text { Engagement }\end{array}$ & 0.242 & 0.068 & 3.561 & 0 & Supported & & 0.074 \\
\hline
\end{tabular}




\begin{tabular}{lllllllll}
\hline H5 & $\begin{array}{l}\text { Customer } \\
\text { Engagement } \rightarrow \\
\text { Repurchase } \\
\text { Intention }\end{array}$ & 0.684 & 0.047 & 14.60 & 0 & Supported & $\mathbf{0 . 4 6 7}$ & 0.877 \\
\hline H6 & $\begin{array}{l}\text { Customer } \\
\text { Engagement } \rightarrow \\
\text { Positive Word of } \\
\text { Mouth }\end{array}$ & 0.607 & 0.054 & 11.278 & 0 & Supported & $\mathbf{0 . 3 6 8}$ & 0.583 \\
& & & & & & & & \\
& & & & & & & & \\
\hline \hline
\end{tabular}

\subsection{Channel-Service Configuration and Customer Engagement}

Contradictory to the original assumption that multiple channel configuration and the transparency of the consistent information should enhance the quality perception by customers and further enhance their willingness to engage with the firm (Lee et al., 2019; Verhoef et al., 2015), channel service configuration did not have a significant relationship with customer engagement. One possible explanation for the insignificant results could be the nature of the industry whereby fastfood restaurants are popular dining options among Malaysian young adult consumers. Despite the high awareness of the different channel configuration options, they do not utilize them. This is reflected by respondent profile information that Malaysian young adult consumers frequented physical fast-food stores. Convenience of location and the operation hours also contribute to the high patronage to physical stores. In Malaysia, delivery services and third-party deliveries are relatively new. This finding is also consistent with Euromonitor report that the younger consumers are found to visit the physical stores 'to see or try before they buy and because they view stores as being more trustworthy than online sales' (Euromonitor International, 2019, p. 17). Importantly, the existing platforms adopted by the fast-food providers have yet to be fully integrated across different platforms which limit the importance of channel integration quality in the test context. In addition, fast-food is considered to be a low involvement product which requires minimum explanation and attention. Consumers do not engage in enthused participation nor connected socially via multiple channels to provide feedbacks or gain technical support from the fast-food restaurant, despite aware of their rights and the availability of multiple channels.

Considering the cultural differences among western and eastern consumers (Ackerman \& Tellis, 2001), Malaysian young adults could have perceived less need to examine the product descriptions (fast-food) during purchase, which lead to less need in utilizing multiple channels to study the product description. In line with social exchange theory (SET), no benefit is perceived being exchanged and therefore no engagement is being fostered (Blau, 2017). Perceived risk such as financial and transactional risks could lead to less dependency on alternative channels by some consumers (Yang et al., 2015).

\subsection{Integrated Interaction and Customer Engagement}

In this study, Integrated Interaction is measured by the content consistency and process consistency. There is no significant relationship found between Integrated Interaction and Customer Engagement $(\beta=0.033, \mathrm{t}<1.645)$, contradicting Lee et al. (2019)'s study. Review of the literature indicates that content consistency is crucial in creating a positive shopping experience. Consistent information across different platforms ensures lesser frustration when consumers move across channels. Process consistency across all platforms creates an atmosphere that allows consumers to 
experience consistent products and services. The consistency of services delivery reduces the chances for misunderstanding and hence fosters engagement between both parties.

However, in this study, the insignificant relationship between Integrated Interaction and Customer Engagement could be possibly due to the lesser need to search on low involvement fast-food product information (Lee et al., 2019). The products offered are relatively simple compared to other high involvement products (e.g., car, houses, and fashion merchandise). The limited product offerings also limit the need for further information searching, hence less need to stress on integrated interaction to create engagement with a fast-food restaurant.

\subsection{Self-Brand Image Congruity and Customer Engagement}

Self-Brand Image Congruity details how consumers' self-images could be reflected by the level of congruency with the brand image. It is postulated that high congruency drives higher customer engagement (Shirkhodaie \& Rastgoo-deylami, 2016). The results of the present study supported Islam et al (2018)'s and Moliner et al. (2018)'s studies that customers with higher congruity tend to have a higher and stronger relationship with a firm. In this study, consumers who perceive a high congruency between themselves with the brand image of the fast-food restaurant they visited will consciously pay attention, socially connected and participated enthusiastically, and these further bring them one step closer to form repurchase intention and spread positive WoM, corroborating Beerli et al. (2007) study. It is also important to note that Self-Brand Image Congruity shows a higher effect size than Value Congruity towards Customer Engagement.

\subsection{Value Congruity and Customer Engagement}

Value Congruity between the customers and firm reflects the extent the products or brands bring both customer and company to shared benefits (Shirkhodaie \& Rastgoo-deylami, 2016). In Shirkhodaie and Rastgoo-deylami (2016)'s study, Value Congruity fosters customer commitment towards the organisation through various engagements to produce intention to spread positive WoM. Similarly, in this study, respondents seem to compare and rationalize the original core values of the fast-food restaurant (e.g. fast delivery services to save dining time; cheap or affordable dining option) and themselves, which allow them to engage with the fast-food restaurants, supporting Islam et al. (2018)'s study.

\subsection{Customer engagement and Post Purchase Behaviours}

Post purchase behaviour is the final stage in the five steps model of consumer purchasing decision which normally triggered by consumer satisfaction (Engel et al., 1995). Repurchase Intention for instance, has been studied by many scholars and mostly associated to customers commitment and loyalty (Erciş et al., 2012; Lee et al., 2019). The findings of this study show that, despite health issue, Malaysian young adult consumers are strong supporters for fast-food products. They consume fast-food at least once a week and spend at least RM10 on every purchase. The findings also show that customer engagement has a large effect size on repurchase intention, corroborating Bitter and Grabner-Kräuter (2016) as well as Christofi et al (2019)'s studies. In other words, customers tend to perform transactional outcomes when they are engaging with a brand. 
Corroborating the findings of Christofi et al. (2019), Lee et al. (2019) and Pick et al. (2010), this study indicates a significant effect of customer engagement on non-transaction outcome such as intention to spread positive WoM. Furthermore, this study has consolidated the result of Pick et al. (2010)'s study that the link between satisfaction and consequences (i.e. WoM) could be customer engagement. Vivek et al. (2012) in their study also proposed that consumers tend to spread positive WoM for the company or brands that they engage with. Looking into the large and medium size effects customer engagement has on repurchase intention and intention to spread positive WoM, fast-food restaurateurs should put greater emphasis on fostering greater engagement with their customers.

\section{IMPLICATIONS, LIMITATIONS, AND RECOMMENDATION}

\subsection{Theoretical Implications}

Utilizing SET and Congruity Theory, the findings of the present study suggested congruity as an important determinant of customer engagement in fast-food restaurant context, while channel integration quality does not play a significant role. The findings also suggested strong effects of customer engagement on both transactional (e.g., repurchase intention) and non-transactional (e.g., intention to spread positive WoM) post purchase outcomes.

From a theoretical point of view, this study expanded Islam et al. (2018)' study to present the findings of a multiracial and multi-religion society. According to Hollebeek (2018), cultural differences could lead to different results in customer engagement effort. Different from Islam et al. (2018)'s study that value congruity plays a large role on customer engagement, Malaysian young adult consumers seem to perceive greater importance of self-brand image congruity. In addition, the findings of this study also indicate that both channel-service configuration and integrated interactions have no significant effect on customer engagement in a low involvement product context (e.g., fast-food restaurant), contradicting Lee et al. (2019)'s study. Lee et al. (2019) concluded both variables are important in the case of high and low involvement products, in which a supermarket brand was used (e.g., Kruger) to represent low involvement product. Compared to fast-food restaurant that offers simple product lines, a supermarket offers large product assortments and varieties. The complicated product categories could have led to greater need of consistency in service channel configuration and integrated interaction. Comparatively, high familiarity toward fast-food products due to its limited product choices and high availability of the fast-food outlets could have contributed to lesser need for channel configuration quality to form customer engagement.

Lastly, this study further strengthens the relationship of the first order constructs towards the second order construct namely customer engagement, channel-service configuration, and integrated interactions. It is a merit to conduct more studies to better understand the determinant and the effect of Customer Engagement.

\subsection{Managerial Implications}

From a managerial point of view, this study suggests that fast-food industry could rely on customer engagement to create positive transactional and non-transactional outcomes. Customer 
engagement is proven to significantly affecting customer behaviours. Despite the concern and awareness of the negative effects of fast-food, Malaysian young adults are found to consume fastfood regularly. Fast-food restaurateurs are suggested to emphasize on forming and developing both self-brand image congruity and value congruity. Marketing programs should be tailored to create events or programs that stress on the self-image as well as personal values that the young adult consumers perceive as important.

Besides, marketing managers should also promote their product core value and expose more information, especially via new media such as social media, company websites and apps which enable their younger customers to form engagement with the brands interactively. Core value should be the key point of differentiation, which may include some "healthy fast-food" value promoted by Subway, fast delivering speed (not less than 30-minutes) by Domino pizza, and a finger-licking good meal promises on good and tasty fried chicken by KFC to their customers. This can be done by acculturating its core values into daily operations as well as their staff's attitude to gain value congruity that further promotes customer's engagement.

Digitalization is a catalyst of change in foodservice industry (Euromonitor International, 2019). Interactive promotional campaigns could be done in the form of online community or member club where interesting activities could be held and promoted easily. The community or member club could be used to draw new members or subscribers through peer recruitment programs, where existing member/subscribers could earn discount coupons or rebates for bringing in new members to the online group. As reported in Euromonitor International (2019), fast-food restaurants should utilize artificial intelligence to better predict dining behaviour and create customised menu offerings to attract consumers. Selling limited edition peripheral toys and introducing party bundles for families on special occasions may help in fostering customer engagement.

\subsection{Limitations}

There were several limitations and challenges conducting this study. Customer engagement was measured using different methods and items in the past studies could have led to confusions. For example, some researchers measure it in second order construct compromising "conscious attention", "enthused participation", and "social connection; some might go for "cognitive processing", "affection", and "activation". Others have different opinions on the position of customer engagement whether it is a determinant or an outcome to "commitment". More studies are needed to examine customer engagement. Secondly, this study only examined customer engagement in the context of fast-food restaurants, which limit the generalizability. The present study only focuses on fast-food restaurants which sell their products via their own online platforms and via the third-party online platforms such as GrabFood and FoodPanda. The future studies could examine how companies which have adopted and integrated more platforms such as the third-party platforms such as Shopee, Zalora, Taobao, Lazada, and private sellers and distributors as they are playing important big roles in online shopping. These online platforms might access to greater customer base than their own online platform which enable engagements to be formed.

In addition, the respondents of the present study, though represent a significant group of consumers and multiracial and multi-religion in nature, does not include the other generation cohorts. Future study could have compared the consumers of different demographical backgrounds. Finally, the findings of the present study also indicated that familiarity could be a concern. The future study 
should consider other product categories to find out how customers are engaged with brands with different levels of involvement and familiarity.

\section{CONCLUSION}

In conclusion, this study inspects customer engagement, its derivation and outcomes in the context of fast-food industry. Adopting social exchange theory and congruity theory, the relationships between channel integration quality and congruity towards customer engagement and the post purchase behavioural outcomes were tested. The finding clarified how customer engagement could positively influence both transactional (i.e., repurchase intention) and emotional (i.e., intention to spread positive WoM) loyalty positively. The study also serves as a basis for future studies and encourages further theoretical and empirical investigation in the territory of customer engagement and omnichannel marketing industry.

\section{REFERENCES}

Aaker, J. L. (1996). Brand Personality: Conceptualization, Measurement and Underlying Psychological Mechanisms [Doctoral dissertation, Stanford University]. Standford Libraries.

Ackerman, D., \& Tellis, G. (2001). Can culture affect prices? A cross-cultural study of shopping and retail prices. Journal of Retailing, 77(1), 57-82.

Alexander, B., \& Cano, M. B. (2019). Futurising the physical store in the omnichannel retail environment. In Exploring Omnichannel Retailing (pp. 197-223). Springer, Cham.

Anderson, E. W. (1998). Customer satisfaction and word of mouth. Journal of Service Research, $1(1), 5-17$.

Bang, Y., Lee, D. J., Han, K., Hwang, M., \& Ahn, J. H. (2013). Channel capabilities, product characteristics, and impacts of mobile channel introduction. Journal of Management Information Systems, 30(2), 101-125.

Beerli, A., Meneses, G. D., \& Gil, S. M. (2007). Self-congruity and destination choice. Annals of Tourism Research, 34(3), 571-587.

Bitner, M. J., Ostrom, A. L., \& Meuter, M. L. (2002). Implementing successful self-service technologies. Academy of Management Perspectives, 16(4), 96-108.

Bitter, S., \& Grabner-Kräuter, S. (2016). Consequences of customer engagement behavior: when negative Facebook posts have positive effects. Electronic Markets, 26(3), 219-231.

Blau, P. M. (2017). Exchange and power in social life ( $\left.2^{\text {nd }} \mathrm{ed}\right)$. London, NY: Routledge

Bowden, J. L. H. (2008). The process of customer engagement: A conceptual framework. Journal of Marketing Theory and Practice, 17(1), 63-74.

Cambra-Fierro, J. J., Melero-Polo, I., \& Vázquez-Carrasco, R. (2013). Customer engagement: Innovation in non-technical marketing processes. Innovation: Management, Policy and Practice, 15(3), 326-336.

Cheah, J. H., Lim, X. J., Ting, H., Liu, Y., \& Quach, S. (2020). Are privacy concerns still relevant? Revisiting consumer behaviour in omnichannel retailing. Journal of Retailing and Consumer Services, 102242.

Cheung, C. M. K., Shen, X., Lee, Z. W. Y., \& Chan, T. K. H. (2015). Promoting sales of online games through customer engagement. Electronic Commerce Research and Applications, 14(4), 241-250. 
Chi, H. K., Yeh, H. R., \& Yang, Y. T. (2009). The impact of brand awareness on consumer purchase intention: The mediating effect of perceived quality and brand loyalty. Journal of International Management Studies, 4(1), 135-144.

Chiu, C. M., Chang, C. C., Cheng, H. L., \& Fang, Y. H. (2009). Determinants of customer repurchase intention in online shopping. Online Information Review, 33(4), 761-784.

Choi, J., Moon, Y., Kim, E., \& Lee, J. H. (2008). The relationship between perceived investments in csr activities and the evaluation of the company. International Journal of Automotive Industry and Management, 2, 33-47.

Cohen, J. (2013). Statistical Power Analysis for the Behavioral Sciences (2 ${ }^{\text {nd }}$ ed). NY: Academic Press.

Christofi, M., Thrassou, A., Chebbi, H., Ahmed, Z. U., Grandhi, B., \& Iaia, L. (2019). CRM campaigns with choice for enhanced business process performance: The collectivist customers' collaborative role for positive word-of-mouth. Business Process Management Journal, 26(5), 1225-1239.

Cropanzano, R., \& Mitchell, M. S. (2005). Social exchange theory: An interdisciplinary review. Journal of Management, 31(6), 874-900.

de Matos, C. A., \& Rossi, C. A. V. (2008). Word-of-mouth communications in marketing: a metaanalytic review of the antecedents and moderators. Journal of the Academy of Marketing Science, 36(4), 578-596.

de Oliveira Santini, F., Ladeira, W. J., Pinto, D. C., Herter, M. M., Sampaio, C. H., \& Babin, B. J. (2020). Customer engagement in social media: A framework and meta-analysis. Journal of the Academy of Marketing Science, 48, 1211-1228.

de Vries, N. J., \& Carlson, J. (2014). Examining the drivers and brand performance implications of customer engagement with brands in the social media environment. Journal of Brand Management, 21(6), 495-515.

Diamantopoulos, A., \& Siguaw, J. A. (2006). Formative versus reflective indicators in organizational measure development: A comparison and empirical illustration. British Journal of Management, 17(4), 263-282.

Emerson, R. M. (1976). Social exchange theory. Annual Review of Sociology, 2, 335-362.

Engel, J. F., Blackwell, R. D., \& Miniard, P. W. (1995). Consumer Behavior (6 ${ }^{\text {th }}$ ed). Chicago, New York.: Dryden Press.

Enz, C. A. (2019). The role of value congruity in intraorganizational power. Administrative Science Quarterly, 33(2), 284-304.

Erciş, A., Ünal, S., Candan, F. B., \& Yıldırım, H. (2012). The effect of brand satisfaction, trust and brand commitment on loyalty and repurchase intentions. Procedia - Social and Behavioral Sciences, 58, 1395-1404.

Euromonitor International. (2019). The Future Consumers of Southeast Asia. Retrieved from Passport database.

Fornell, C., \& Larcker, D. F. (2018). Structural equation models with unobservable variables and measurement error: Algebra and statistics. Journal of Marketing Research, 18(3), 382-388.

Gabisch, J. A., \& Gebwu, K. L. (2011). Impact of virtual brand experience on purchase intentions : the role of multichannel congruence. Journal of Electronic Commerce Research, 12(4), 302 320.

Gao, F., \& Su, X. (2017). Online and offline information for omnichannel retailing. Manufacturing \& Service Operations Management, 19(1), 84-98.

Grant, M. (2018, December 14 $\left.{ }^{\text {th }}\right)$. Where retailers are placing their omnichannel bets in 2019. Forbes. https://www.forbes.com/sites/michellegrant/2018/12/14/where-retailers-are-placing 
-their-omnichannel-bets-in-2019/?sh=7593dbbf7e29

Guo, L., Gruen, T. W., \& Tang, C. (2017). Seeing relationships through the lens of psychological contracts: the structure of consumer service relationships. Journal of the Academy of Marketing Science, 45(3), 357-376.

Hair, J. F., Black, W. C., Babin, B. J., \& Anderson, R. E. (2010). Multivariate Data Analysis: A Global Perspective ( $7^{\text {th }}$ ed). New Jersey: Pearson Prentice Hall.

Hair, J. F., Hopkins, L., Georgia, M., \& College, S. (2008). Partial least squares structural equation modeling (PLS-SEM ): An emerging tool in business research. European Business Review, 26(2), 106-121.

Hair Jr, J. F., Hult, G. T. M., Ringle, C., \& Sarstedt, M. (2017). A Primer on Partial Least Squares Structural Equation Modeling (PLS-SEM) ( $2^{\text {nd }}$ ed). Sage publications.

Harrigan, P., Evers, U., Miles, M. P., \& Daly, T. (2018). Customer engagement and the relationship between involvement, engagement, self-brand connection and brand usage intent. Journal of Business Research, 88, 388-396.

Hellier, P. K., Geursen, G. M., Carr, R. A., \& Rickard, J. A. (2003). Customer repurchase intention. European Journal of Marketing, 37(11/12), 1762-1800.

Hollebeek, L. D. (2018). Individual-level cultural consumer engagement style: Conceptualization, propositions and implications. International Marketing Review, 35(1), 42-71.

Hollebeek, L. D., Conduit, J., \& Brodie, R. J. (2016). Strategic drivers, anticipated and unanticipated outcomes of customer engagement. Journal of Marketing Management, 32(56), 393-398.

Islam, J. U., Rahman, Z., \& Hollebeek, L. D. (2018). Consumer engagement in online brand communities: a solicitation of congruity theory. Internet Research, 28(1), 23-45.

Islam, J. U., Hollebeek, L. D., Rahman, Z., Khan, I., \& Rasool, A. (2019). Customer engagement in the service context: an empirical investigation of the construct, its antecedents and consequences. Journal of Retailing and Consumer Services, 50, 277-285.

Kelley, H. H., \& Thibaut, J. W. (1978). Interpersonal Relations: A Theory of Interdependence. NY: John Wiley \& Sons.

Kline, R. B. (2015). Principles and Practice of Structural Equation Modeling (3 ${ }^{\text {rd }}$ ed). Guilford publications.

Kock, N., \& Lynn, G. S. (2012). Lateral collinearity and misleading results in variance-based SEM : An illustration and recommendations lateral collinearity and misleading results in variance. Journal of the Association of Information System, 13(7), 546-580.

Kumar, V., \& Pansari, A. (2016). Competitive advantage through engagement. Journal of Marketing Research, 53(4), 497-514.

Larasati, Y., \& Hananto, A. (2012). The role of value congruity and consumer brand identification toward development of brand commitment and positive word of mouth. SSRN Electronic Journal.

Lawler, E. J. (2001). An affect theory of social exchange. American Journal of Sociology, 107(2), $321-352$.

Lee, Z. W., Chan, T. K., Chong, A. Y. L., \& Thadani, D. R. (2019). Customer engagement through omnichannel retailing: The effects of channel integration quality. Industrial Marketing Management, 77, 90-101.

Lee, S., \& Jeong, M. (2014). Enhancing online brand experiences: An application of congruity theory. International Journal of Hospitality Management, 40, 49-58.

Loiacono, E. T., Watson, R. T., \& Goodhue, D. L. (2007). WebQual: An instrument for consumer evaluation of web sites. International Journal of Electronic Commerce, 11(3), 51-87. 
Marshall, M. N. (1996). Sampling for qualitative research Sample size. Family Practice, 13(6), $522-525$.

Maslowska, E., Malthouse, E. C., \& Collinger, T. (2016). The customer engagement ecosystem. Journal of Marketing Management, 32(5-6), 469-501.

Moliner, M. Á., Monferrer-Tirado, D., \& Estrada-Guillén, M. (2018). Consequences of customer engagement and customer self-brand connection. Journal of Services Marketing, 32(4), 387399.

Moran, G., Muzellec, L., \& Nolan, E. (2014). Consumer moments of truth in the digital context. Journal of Advertising Research, 54(2), 200-204.

Nijssen, E., Singh, J., Sirdeshmukh, D., \& Holzmüeller, H. (2003). Investigating industry context effects in consumer-firm relationships: Preliminary results from a dispositional approach. Journal of the Academy of Marketing Science, 31(1), 46-60.

Oh, L. B., \& Teo, H. H. (2010). Consumer value co-creation in a hybrid commerce service-delivery system. International Journal of Electronic Commerce, 14(3), 35-62.

Orendorff, A. (2018). Omni-channel retail strategy: The what, why, and how of "in-store" shopping. Omni-Channel. https://www.shopify.com/enterprise/omni-channel-retail-strategy

Osborne, J. W., \& Costello, A. B. (2005). Best practices in exploratory factor analysis: Four recommendations for getting the most from your analysis. Practical Assessment Research \& Evaluation, 10(7), 1-9.

Park, J., \& Kim, R. B. (2019). The effects of integrated information \& service, institutional mechanism and need for cognition (NFC) on consumer omnichannel adoption behavior. Asia Pacific Journal of Marketing and Logistics, 33(6), 1386-1414.

Phua, J., \& Kim, J. (2018). Starring in your own Snapchat advertisement: Influence of self-brand congruity, self-referencing and perceived humor on brand attitude and purchase intention of advertised brands. Telematics and Informatics, 35(5), 1524-1533.

Pick, D., Mittal, V., Verhoef, P. C., Lemon, K. N., van Doorn, J., Pirner, P., \& Nass, S. (2010). Customer engagement behavior: Theoretical foundations and research directions. Journal of Service Research, 13(3), 253-266.

Piotrowicz, W., \& Cuthbertson, R. (2014). Introduction to the special issue information technology in retail: toward omnichannel retailing. International Journal of Electronic Commerce, 18(4), $5-16$.

Podsakoff, P. M., MacKenzie, S. B., Lee, J. Y., \& Podsakoff, N. P. (2003). Common method biases in behavioral research: A Critical review of the literature and recommended remedies. Journal of Applied Psychology, 88(5), 879-903.

Saghiri, S., Wilding, R., Mena, C., \& Bourlakis, M. (2017). Toward a three-dimensional framework for omni-channel. Journal of Business Research, 77, 53-67.

Sashi, C. M. (2012). Customer engagement, buyer-seller relationships, and social media. Management Decision, 50(2), 253-272.

Schoenbachler, D. D., \& Gordon, G. L. (2002). Multi-channel shopping: Understanding what drives channel choice. Journal of Consumer Marketing, 19(1), 42-53.

Sekaran, U. \& Bougi, R. (2014). Research Methods for Business: A Skill-Building Approach $\left(7^{\text {th }}\right.$ ed). John Wiley \& Sons.

Shirkhodaie, M., \& Rastgoo-deylami, M. (2016). Positive word of mouth marketing: explaining the roles of value congruity and brand love. Journal of Competitiveness, 8(1), 19-37.

Simon, C., Brexendorf, T. O., \& Fassnacht, M. (2016). The impact of external social and internal personal forces on consumers' brand community engagement on Facebook. Journal of Product \& Brand Management, 25(5), 409-423. 
Sousa, R., \& Voss, C. (2004). Operations and technology management service quality in multichannel services. Operations and Technology Management Working Paper Otm 04-023 2004/12/09, 44, 0-46.

Sousa, R., \& Voss, C. A. (2006). Service quality in multichannel services employing virtual channels. Journal of Service Research, 8(4), 356-371.

Srivastava, K., \& Sharma, N. K. (2013). Service quality, corporate brand image, and switching behavior: the mediating role of customer satisfaction and repurchase intention. Services Marketing Quarterly, 34(4), 274-291.

Tannenbaum, P. H., \& Osgood, C. E. (1955). The principle of congruity in the prediction of attitude change. Psychological Review, 62(1), 42-55.

Tseng, Y. M., Liao, B. C., \& Jan, Y. S. (2004). The study of relation between product value, brand trust, brand affect and brand loyalty. Journal of Business Administration, 61(1), 29-50.

Verhoef, P. C., Kannan, P. K., \& Inman, J. J. (2015). From multi-channel retailing to omni-channel retailing. Journal of Retailing, 91(2), 174-181.

Verleye, K., Gemmel, P., \& Rangarajan, D. (2014). Managing engagement behaviors in a network of customers and stakeholders: Evidence from the nursing home sector. Journal of Service Research, 17(1), 68-84.

Vivek, S. D., Beatty, S. E., Dalela, V., \& Morgan, R. M. (2014). A generalized multidimensional scale for measuring customer engagement. Journal of Marketing Theory and Practice, 22(4), 401-420.

Vivek, S. D., Beatty, S. E., \& Morgan, R. M. (2012). Customer engagement: Exploring customer relationships beyond purchase. Journal of Marketing Theory and Practice, 20(2), 122-146.

Wakolbinger, L. M., \& Stummer, C. (2013). Multi-channel management: an exploratory study of current practices. International Journal of Services, Economics and Management, 5(1/2), 112.

Wong, H. Y., \& Merrilees, B. (2015). An empirical study of the antecedents and consequences of brand engagement. Marketing Intelligence \& Planning, 33(44), 575-591.

Wong, K. W. (2020, March 11). Embracing the retail omni-channel experience. The Edge Malaysia. https://www.theedgemarkets.com/article/cover-story-embracing-retail-omni channel-experience

Yang, Q., Pang, C., Liu, L., Yen, D. C., \& Michael Tarn, J. (2015). Exploring consumer perceived risk and trust for online payments: An empirical study in China's younger generation. Computers in Human Behavior, 50, 9-24.

Zainol, Z., Omar, N. A., Osman, J., \& Habidin, N. F. (2016). The effect of customer-brand relationship investments' dimensions on customer engagement in emerging markets. Journal of Relationship Marketing, 15(3), 172-199.

Zhang, M., Hu, M., Guo, L., \& Liu, W. (2017). Understanding relationships among customer experience, engagement, and word-of-mouth intention on online brand communities. Internet Research, 24(4), 839-857. 